\title{
Geochemical isotopic composition in the Loess Plateau and corresponding source analyses: A case study of China's Yangjuangou catchment
}

\author{
Yafeng Wang a,c , Liding Chen ${ }^{\mathrm{a}, \mathrm{c}}$, Yang Gao ${ }^{\mathrm{b}, \mathrm{c}, *}$, Shibo Chen ${ }^{\mathrm{d}}$, Weiliang Chen ${ }^{\mathrm{a}, \mathrm{c}}$, Zhuo Hao ${ }^{\mathrm{b}, \mathrm{c}}$, \\ Junjie Jia ${ }^{\mathrm{b}, \mathrm{c}}$, Ning Han ${ }^{\mathrm{b}, \mathrm{c}}$ \\ a State Key Laboratory of Urban and Regional Ecology, Research Center for Eco-Environmental Sciences, Chinese Academy of Sciences, Beijing 100085, China \\ ${ }^{\mathrm{b}}$ Key Laboratory of Ecosystem Network Observation and Modeling, Institute of Geographic Sciences and Natural Resources Research, Chinese Academy of Sciences, Beijing 100101, China \\ c College of Resources and Environment, University of Chinese Academy of Sciences, Beijing 100049, China \\ d College of Geoscience and Surveying Engineering, China University of Mining and Technology (Beijing), Beijing 100083, China
}

\section{A R T I C L E I N F O}

\section{Article history:}

Received 20 September 2016

Received in revised form 22 December 2016

Accepted 2 January 2017

Available online 6 January 2017

Editor: D. Barcelo

\section{Keywords:}

Loess Plateau

Isotopic fractionation

Carbon

Nitrogen

Oxygen

Hydrogen

\begin{abstract}
A B S T R A C T
Isotopic fractionation technology is widely used in identifying sources and the speciation of geochemical isotopic elements. With the increase in human activity, geochemical element transport by soil erosion has become the most critical environmental problem in the Loess Plateau, so tracing the geochemical element source would help in the identification and management of local soil erosion. In this study, we investigated the spatial distribution of carbon $(\mathrm{C})$, nitrogen $(\mathrm{N})$, oxygen $(\mathrm{O})$, and hydrogen $(\mathrm{H})$ isotopes in water and then further analyzed ${ }^{13} \mathrm{C}$ and ${ }^{15} \mathrm{~N}$ in soil and vegetation to better understand the $\mathrm{C}$ and $\mathrm{N}$ sources and their biogeochemical cycling function in the Loess Plateau. Results showed that mean dual isotopic values of $\delta^{15} \mathrm{~N}^{-\mathrm{NO}_{3}^{-}}$and $\delta^{18} \mathrm{O}-\mathrm{NO}_{3}^{-}$in the watershed streams were $11.44 \pm 6.15 \%$ and $-11.29 \pm 2.52 \%$, respectively, and that $\mathrm{N}$ wet deposition, fertilizers, and manure were the three main pollution sources. The mean dual isotopic value of $\delta^{13} \mathrm{C}$ in the water was $-5.36 \pm$ $0.28 \%$, indicating that $\delta^{13} \mathrm{C}$-DIC in the Yangjuangou Catchment of China's Loess Plateau is mainly controlled by carbonate weathering or soil erosion. The severe erosion in this region has typically occurred in grassy $\left(\mathrm{C}_{4}\right)$ land-use types devoid of woody vegetation $\left(C_{3}\right)$, and this has led to a discrepancy in $\delta^{13} \mathrm{C}$ between soil and water. We found $\delta^{18} \mathrm{O}$ and $\delta^{2} \mathrm{D}$ in water to be $-7.87 \pm 0.85 \%$ and $-61.49 \pm 3.25 \%$, respectively, and to show a high positive correlation $\left(r^{2}=0.81\right)$. This suggests that summer rainstorms lead to soil erosion and runoff, which cause a wide range of isotopic values to occur across the Loess Plateau.
\end{abstract}

(c) 2017 Elsevier B.V. All rights reserved.

\section{Introduction}

The Loess Plateau covers an area of $640,000 \mathrm{~km}^{2}$. It is located in the upper and middle reaches of China's Yellow River, where more than $60 \%$ of the land is susceptible to soil and water loss (Wang et al., 2014). Owing to this, nutrients are highly susceptible to transport by soil and water during rainfall events. This nutrient export is compounded by anthropogenic activity and industrial and agricultural emissions, which accelerate nutrient deposition and discharge into aquatic ecosystems. Yue et al. (2015), for example, reported significant amounts of carbon $(\mathrm{C})$ and nitrogen $(\mathrm{N})$ in water due to the excessive use of fertilizers from agricultural activities in southwest China. Therefore, identifying the $\mathrm{C}$ and $\mathrm{N}$ sources and understanding the

\footnotetext{
* Corresponding author at: Key Laboratory of Ecosystem Network Observation and Modeling, Institute of Geographic Sciences and Natural Resources Research, Chinese Academy of Sciences, Beijing 100101, China.

E-mail address: gaoyang@igsnrr.ac.cn (Y. Gao).
}

biogeochemical cycling functions across the Loess Plateau is critical for improving local nutrient management practices as well as water quality.

During $\mathrm{N}$ biotransformation processes, biological discrimination between ${ }^{14} \mathrm{~N}$ and ${ }^{15} \mathrm{~N}$, two stable isotopes, leads to natural isotopic fractionation. The lighter form of ${ }^{14} \mathrm{~N}$ is easily removed at higher rates than the heavier form of ${ }^{15} \mathrm{~N}$, which leads to an increase in ${ }^{15} \mathrm{~N}$ concentration values for the remaining product (Miller et al., 2010). Thus, stable isotope ratios of $\delta^{14} \mathrm{~N}-\mathrm{NO}_{3}^{-} / \delta^{15} \mathrm{~N}-\mathrm{NO}_{3}^{-}$have been widely applied in aquatic ecosystems to identify different sources of $\mathrm{NO}_{3}^{-}$, such as wastewater, $\mathrm{N}$ deposition, man-made fertilizers, and animal waste (Kendall, 1998; Masetti et al., 2008; Pennino et al., 2014). As it relates to river sediment, $\mathrm{N}$ biotransformation starts with $\mathrm{N}$ assimilation, followed by $\mathrm{N}$ removal through dissimilatory reduction via denitrification. Under rainfall scenarios, ${ }^{15} \mathrm{~N}$ values in sediment in polluted areas would eventually be higher compared to unpolluted river areas. Thus, stable $\mathrm{N}$ isotope ratios $\left({ }^{15} \mathrm{~N} /{ }^{14} \mathrm{~N}\right)$ can be used as a reliable indicator of $\mathrm{N}$ sources. However, for watersheds, it is better to identify major $\mathrm{N}$ sources via river monitoring (Kendall et al., 2007; Mengis et al., 2001). 
Previous studies have demonstrated that stable isotopes $\left(\delta^{15} \mathrm{~N}\right.$ and $\delta^{18} \mathrm{O}$ ) of nitrates can be successfully used to elucidate sources of $\mathrm{NO}_{3}^{-}$ in water based on sources with distinct isotopic signatures (Liu et al., 2006; McMahon and Böhlke, 2006; Panno et al., 2006). Many comprehensive studies have used dual isotope analyses to assess sources and transformations of nitrates in groundwater and rivers (Heaton et al., 2012). Opposing isotope fractionation effects from variations in concentrations and isotopic composition make it possible to distinguish between sorption, nitrification, and denitrification, which are major processes that affect $\mathrm{N}$ distribution under field settings. Therefore, the combination of $\delta^{18} \mathrm{O}-\mathrm{NO}_{3}^{-}$can be considered a more reliable indicator of denitrification processes (Kendall, 1998; Wassenaar et al., 2011).

Different mechanisms of $\mathrm{C}$ fixation result in different isotope fractionations. $\delta{ }^{13} \mathrm{C}$ values obtained from plant organic matter reflect the pathways of C fixation in plants (Garcin et al., 2014), whereas $\delta^{13} \mathrm{C}$ within the dissolved inorganic carbon (DIC) reservoir is mainly dominated by exchanges with respiration of plants, atmospheric $\mathrm{CO}_{2}$, the dissolution of carbonate rocks by chemical weathering, oxidation of organic matter, and biological activity in water itself (Brunet et al., 2005; Schulte et al., 2011). Therefore, investigations into C isotopes provide further information related to sources and the evolution of DIC. In addition, elements of ${ }^{18} \mathrm{O}$ and ${ }^{2} \mathrm{D}$ isotopes in stream and lake water are good indicators of sources and transport pathways of incoming precipitation (Wassenaar et al., 2011). $\delta^{18} \mathrm{O}$ and $\delta^{2} \mathrm{D}$ in soil water have also been used to indicate evaporation, infiltration, and mixing processes as well as to quantitatively estimate groundwater recharge and evaporation rates (Cheng and Liu, 2014; Liu, 2011; Liu et al., 2015). Additionally, the analysis of the isotopic composition of $\delta^{18} \mathrm{O}$ and $\delta^{2} \mathrm{D}$ in soil water has been widely used to characterize infiltration profiles and evaporation rates in arid and semiarid regions (Schachtschneider and February, 2007; Wan and Liu, 2016).

In this study, we investigated spatial variations of geochemical isotopic characteristics in the Yangjuangou Catchment of the Loess Plateau, China. The aim of our study was to: (1) determine the isotopic characteristics of $\delta^{15} \mathrm{~N}$ and $\delta^{18} \mathrm{O}$ for $\mathrm{NO}_{3}^{-}$and of $\delta^{18} \mathrm{O}, \delta^{2} \mathrm{D}$, and $\delta^{13} \mathrm{C}$ for DIC in runoff; (2) ascertain $\delta^{15} \mathrm{~N}$ and $\delta^{13} \mathrm{C}$ for total carbon (TC) and total organic carbon (TOC) in soil and plants; and (3) provide a comprehensive understanding of the origin of the isotopic composition of $\mathrm{C}$ and $\mathrm{N}$ in the catchment area.

\section{Materials and methods}

\subsection{Study area}

Our study area, the Yangjuangou Catchment, is located in the middle region of the Loess Plateau in northern Shaanxi Province, China $\left(36^{\circ} 42^{\prime}\right.$ $\mathrm{N}, 109^{\circ} 31^{\prime} \mathrm{E}$ ) (Fig. 1a). This region is characterized by large topographic variations with loess hills and gully land-use types that have maximum altitudinal differences from hill top to gully bottom of $225 \mathrm{~m}$ and a gully density of $2.74 \mathrm{~km}^{2}$ (Wang et al., 2010, 2011). The climate is a semiarid continental type with an average annual rainfall of $535 \mathrm{~mm}$ that mainly occurs from July to September and exhibits high inter-annual variation. The soil type is Loess, which is a fine silt to silt in and weakly resistant to erosion. Cultivation in the study area has eradicated natural vegetation,

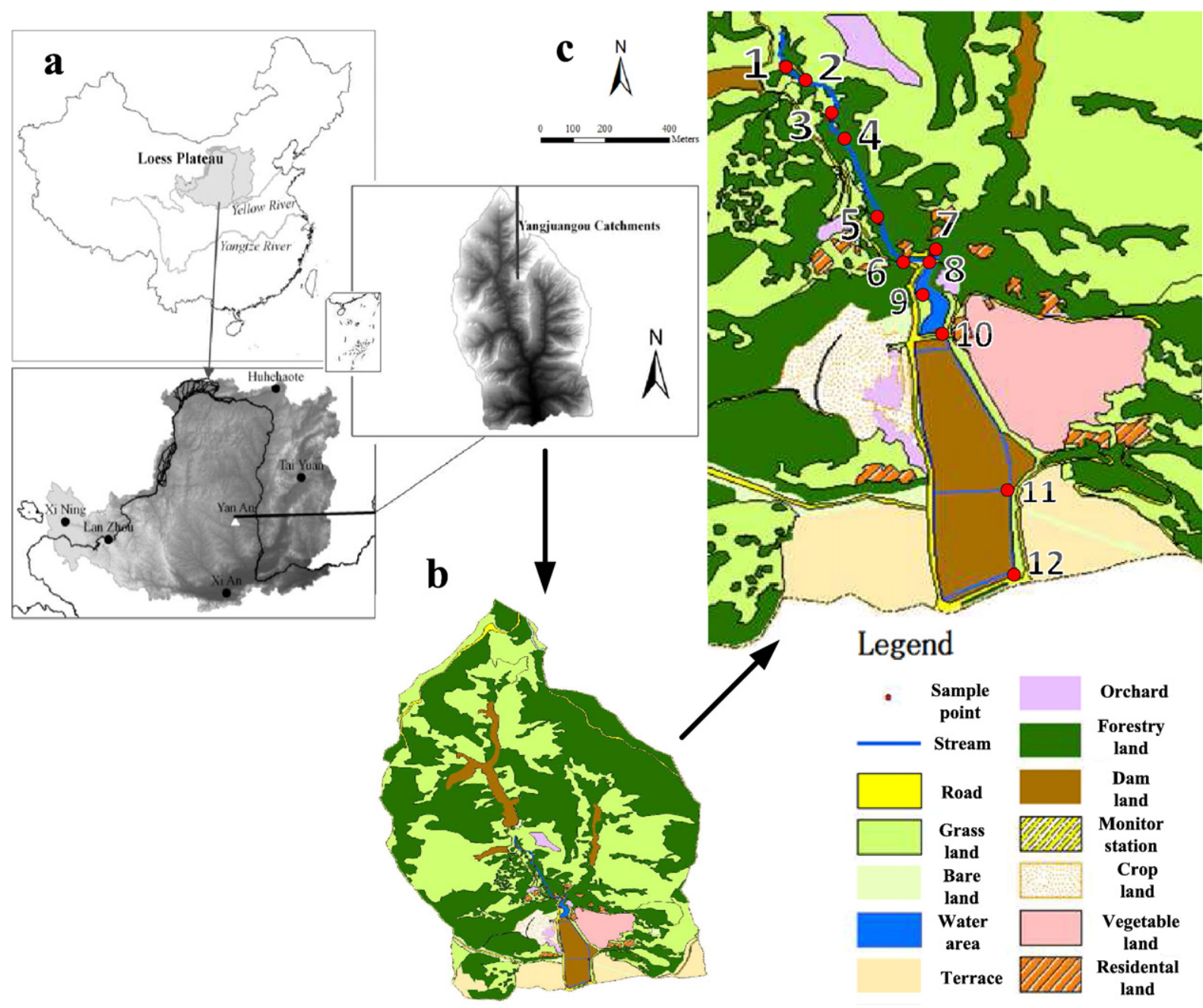

Fig. 1. Geographic location of the Yangjuangou Catchment (a), change of land use (b), and sample points (c). Terrace, cropland, and vegetable land are classified as farmland. 
and after years of rehabilitation, many changes have taken place within the agricultural landscape (Wang et al., 2011).

Grass, shrub, forest, and farmland are the four main land-use types that characterize this watershed. The primary grass species are Artemisia Linn, Elymus repens, and small weeds, while the primary shrubs are Prunus armeniaca and Hippophae rhamnoides in mature forests and Robinia pseudoacacia in young forests. The mountains that surround the catchment act as its boundary. Owing to its natural topography and lower elevation, runoff from each tributary catchment can converge and export water from a single outlet. This makes the watershed a good representation of a closed system (Fig. 1b).

\subsection{Sampling and analysis}

We collected water, soil, and plant samples from July to October 2015. Twelve locations were selected as water sampling points based on the spatial distribution and land-use types in the catchment (Fig. 1c). Soil samples were collected at a 1-m depth from dam, forest, farm, and grassland land covers; mixed samples were also taken. We selected four typical species for vegetation isotopic analysis: Pterocarya stenoptera, Salix babylonica L., Stipa bungeana Trin., and Agropyron cristatum.

Sampled water was filtered through an organic microporous membrane with a pore size of $0.45 \mu \mathrm{m}$. We heated the filtered samples to $80^{\circ} \mathrm{C}$ in water and maintained this temperature for $12 \mathrm{~h}$ to remove impurities. A segmented continuous flow analyzer (AA3; Germany) was used to measure total nitrogen (TN) and total organic carbon (TOC). Dissolved nitrate $\delta^{15} \mathrm{~N}-\mathrm{NO}_{3}^{-}$and $\delta^{18} \mathrm{O}-\mathrm{NO}_{3}^{-}$were quantified using the denitrifier method with samples split into two groups depending on $\mathrm{NO}_{3}^{-}$, as described in detail by Proemse et al. (2012). Isotope ratios were calculated as $\delta^{15} \mathrm{~N}$ values versus air (atmospheric $\mathrm{N}_{2}$ ) by comparing them with standards calibrated against International Atomic Energy Agency $\mathrm{N}-1$ and $\mathrm{N}-2$. We also analyzed ${ }^{18} \mathrm{O} /{ }^{16} \mathrm{O} \mathrm{NO}_{3}^{-}$ratios using thermal conversion to $\mathrm{CO}$ gas at $1400{ }^{\circ} \mathrm{C}$ in a TC/EA high-temperature conversion elemental analyzer connected online to a Deltaplus XL mass spectrometer (Thermo Finnigan, Bremen, Germany).

We used $0.5 \% \mathrm{CO}_{2} / \mathrm{He}$ or an $\mathrm{H}_{2} / \mathrm{He}$ gas mix to obtain oxygen ( $\mathrm{O}$ ) and hydrogen $(\mathrm{H})$ isotope ratios, as described in detail by Weynell et al. (2016), and conducted $\mathrm{O}$ and $\mathrm{H}$ stable isotopic measurements on water samples using the Liquid Water Isotope Analyzer (Picarro, USA). $\delta^{13} \mathrm{C}$-DIC was determined by injecting $0.2,0.5$, and $1.0 \mathrm{~mL}$ of sample solution into He-rinsed glass vials (Exetainer) (Spötl, 2005) and analyzing the $\delta^{13} \mathrm{C}$-DIC with a Deltaplus XL mass spectrometer (Thermo Finnigan). For the isotopic composition of $\mathrm{C}$ and $\mathrm{N}$ of the collected vegetation, a ball mill was used to ground dry leaves, and then between 2 and $3 \mathrm{mg}$ was weighed into tin capsules, following the methods by Lehmitz and Maraun (2016). $\delta^{13} \mathrm{C}$ and $\delta^{15} \mathrm{~N}$ of the four species were determined using a mass spectrometer (Thermo Finnigan). Finally, we determined soil $\mathrm{C}$ and $\mathrm{N}$ content and the associated isotopic composition of $\mathrm{C}$ and $\mathrm{N}$ using an element analyzer and mass spectrometer (Thermo Fisher Scientific, Bremen, Germany).

$\mathrm{C}, \mathrm{N}, \mathrm{H}$, and $\mathrm{O}$ isotope ratios were expressed as delta values as follows:

$\delta^{y} \mathrm{X}=\left(\frac{R_{\text {sample }}}{R_{\text {ref.std. }}}-1\right) \times 1000$,

where $\mathrm{X}$ represents the target isotope; $y$ represents the amount of atoms; and $R$ represents the ratio of heavy to light isotopes, e.g., ${ }^{13} \mathrm{C} /{ }^{12} \mathrm{C}$.

\section{Results}

\subsection{Variations in $C$ and $N$ concentrations in water}

Concentrations of TC from different locations in the Yangjuangou Catchment ranged from 33 to $107 \mathrm{mg} \cdot \mathrm{L}^{-1}$ with a mean value of
$82.3 \pm 17.9 \mathrm{mg} \cdot \mathrm{L}^{-1}$ (Fig. 2a). The majority of these concentrations were above $70 \mathrm{mg} \cdot \mathrm{L}^{-1}$, the exception being that at sample point 11 . Concentrations of TIC ranged from 5 to $93 \mathrm{mg} \cdot \mathrm{L}^{-1}$ with a mean value of $57.3 \pm 33.5 \mathrm{mg} \cdot \mathrm{L}^{-1}$; TIC showed significant fluctuations and instability in the watershed. We detected relatively low TOC concentrations except at sample points $6\left(74.4 \mathrm{mg} \cdot \mathrm{L}^{-1}\right)$ and $7\left(69.8 \mathrm{mg} \cdot \mathrm{L}^{-1}\right)$; samples had a mean TOC value of $25.0 \pm 25.7 \mathrm{mg} \cdot \mathrm{L}^{-1}$.

In contrast to $C$ concentrations, variations in $\mathrm{N}$ concentrations showed a descending trend from sample point 1 to 12 (Fig. 2b). TN concentrations ranged from 2.2 to $22.9 \mathrm{mg} \cdot \mathrm{L}^{-1}$ with a mean value of $9.2 \pm$ $7.9 \mathrm{mg} \cdot \mathrm{L}^{-1}$ but were only 2.2 and $2.9 \mathrm{mg} \cdot \mathrm{L}^{-1}$ at the outlet of the watershed. Similarly, DTN concentrations ranged from 0.5 to $16.3 \mathrm{mg} \cdot \mathrm{L}^{-1}$ (mean $6.9 \pm 7.3 \mathrm{mg} \cdot \mathrm{L}^{-1}$ ).

\subsection{Composition of isotopes in water}

The isotopic composition of $\mathrm{C}, \mathrm{O}$, and $\mathrm{H}$ from the upstream point to the outlet of the catchment is shown in Fig. 3a. Dual isotopic values of $\delta^{13} \mathrm{C}$ ranged from $-4.58 \%$ o to $-5.58 \%$, with a mean value of $-5.36 \pm 0.28 \%$ and with sample points 3 and 4 having the highest values. $\delta^{18} \mathrm{O}$ exhibited similar trends to $\delta^{13} \mathrm{C}$ and showed small fluctuations and a mean value of $-7.87 \pm 0.85 \%$. $\delta^{2} \mathrm{D}$ was higher midstream, and its mean dual isotopic value was $-61.49 \pm 3.25 \%$, ranging from $57.10 \%$ o to $-67.23 \%$. We detected distinct spatial distributions in $\delta^{15} \mathrm{~N}$ $\mathrm{NO}_{3}^{-}$and $\delta^{18} \mathrm{O}-\mathrm{NO}_{3}^{-}$values in the catchment, with $\delta^{15} \mathrm{~N}-\mathrm{NO}_{3}^{-}$having a greater variation relative to $\delta^{18} \mathrm{O}-\mathrm{NO}_{3}^{-}$(Fig. 3b). $\delta^{15} \mathrm{~N}-\mathrm{NO}_{3}^{-}$had a mean dual isotopic value of $11.44 \pm 6.15 \%$, ranging from $0.22 \%$ o to $20.52 \%$ with the lowest value at sample point 8 and the highest at sample point 2 . Although $\delta^{18} \mathrm{O}-\mathrm{NO}_{3}^{-}$showed smaller changes relative to ${ }^{15} \mathrm{~N}-\mathrm{NO}_{3}^{-}, \delta^{18} \mathrm{O}-\mathrm{NO}_{3}^{-}$showed higher fluctuations compared to $\delta^{18} \mathrm{O}$.
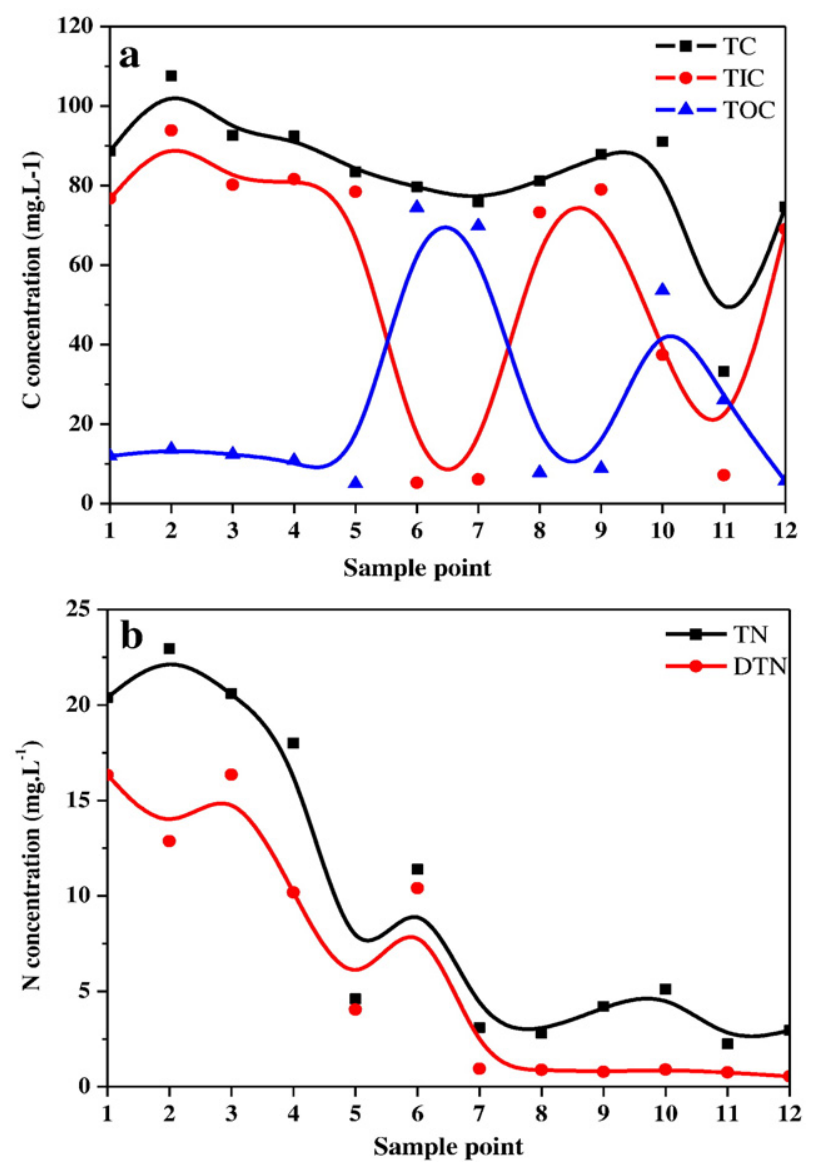

Fig. 2. Spatial variation of different forms of $C(a)$ and $N(b)$ at different location in the Yangjuangou Catchment. 

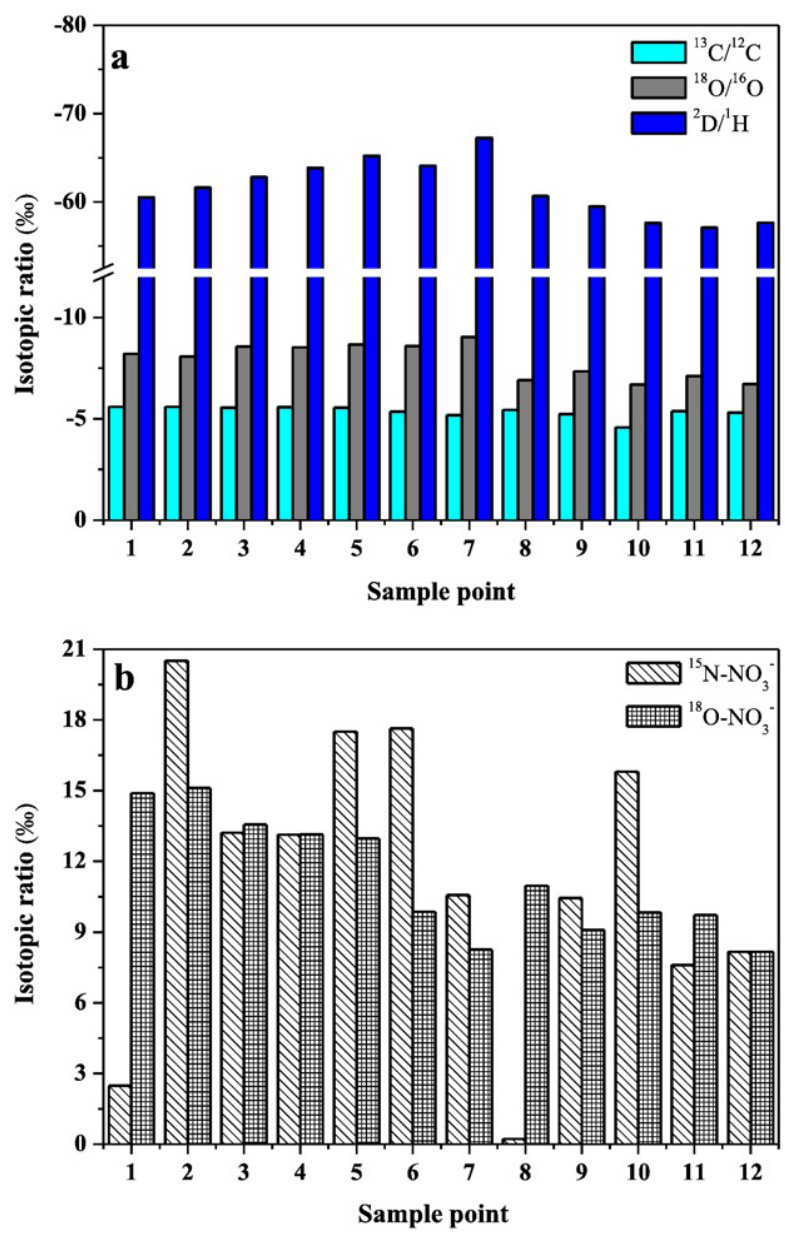

Fig. 3. Spatial variation of stable isotopic $\mathrm{C}, \mathrm{O}$, and $\mathrm{H}(\mathrm{a})$ and ${ }^{15} \mathrm{~N}$ and ${ }^{18} \mathrm{O}$ of nitrate (b) at different locations in the Yangjuangou Catchment.

Dual isotopic values of $\delta^{18} \mathrm{O}-\mathrm{NO}_{3}^{-}$ranged from $8.25 \%$, to $15.11 \%$, with a mean value of $-11.29 \pm 2.52 \%$.

\subsection{Changes in $C$ and $N$ and associated isotopic characteristics in soil and plants}

The four land-use types of the Loess Plateau sampled in this study were dam, grass, forest, and farmland. As Fig. 4 shows, dams had the highest TN and TOC of 5.76 and $190.72 \mathrm{mg} \cdot \mathrm{kg}^{-1}$, respectively. Among the four land-use types, soil TN was in the following descending order: $\operatorname{dam}\left(4.52 \pm 1.08 \mathrm{mg} \cdot \mathrm{kg}^{-1}\right)>$ forest $(4.49 \pm 0.16 \mathrm{mg}$

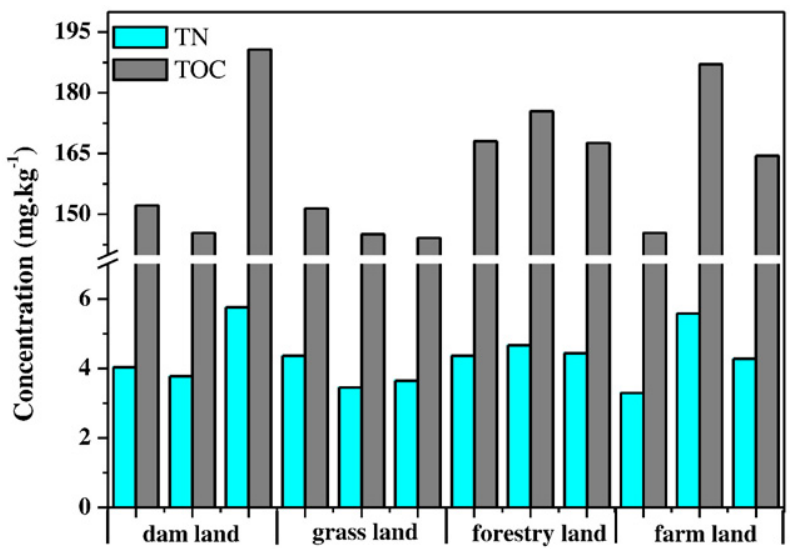

Fig. 4. Change in soil $\mathrm{C}$ and $\mathrm{N}$ under different land uses in the Yangjuangou Catchment. $\mathrm{kg}^{-1}$ ) $>$ farm $>$ grassland. In contrast, TOC in soil was in the following descending order: forest $>$ farm $>$ dam $>$ grassland. The average TOC value for dams was $162.76 \pm 24.44 \mathrm{mg} \cdot \mathrm{kg}^{-1}$, while forests had the highest average TOC value overall $\left(170.39 \pm 4.44 \mathrm{mg} \cdot \mathrm{kg}^{-1}\right)$.

Dual isotopic values of $\delta^{13} \mathrm{C}$-TC showed notable differences in the different land-use types, whereas dual isotopic values of $\delta^{13} \mathrm{C}$-TOC showed little variation (Fig. 5a). Dual isotopic values of $\delta^{13} \mathrm{C}$-TOC were $-25.83 \pm 0.52 \%$ 。 (dams), $-27.67 \pm 0.72 \%$ (grassland), $-26.87 \pm$ $0.23 \%$ (forests), and $-24.22 \pm 0.56 \%$ o (farmland). In contrast, dual isotopic values of $\delta^{13} \mathrm{C}$-TC were $-12.12 \pm 6.59 \%$ (forests), $-8.81 \pm$ $0.88 \%$ 。 (farmland), $-8.78 \pm 2.19 \%$ (grassland), and $-6.07 \pm 0.18 \%$ 。 (dams). Dual isotopic values of $\delta^{15} \mathrm{~N}$ also exhibited significant differences: $8.19 \pm 0.15 \%$ o(farmland), $6.09 \pm 0.67 \%$ o(forests), $5.77 \pm$ $0.64 \%$ (grassland), and $5.36 \pm 3.8 \%$ (dams) (Fig. $5 b$ ).

In order to better understand the isotopic composition of the catchment, we also analyzed the composition of ${ }^{13} \mathrm{C}$ and ${ }^{15} \mathrm{~N}$ in the four main species of vegetation in the watershed. Dual isotopic values of $\delta^{13} \mathrm{C}$ for $P$. stenoptera, S. babylonica L., St. bungeana Trin., and A. cristatum were $-27.03 \pm 3.25 \%$, $-26.7 \pm 2.78 \%,-30.63 \pm 1.23 \%$, and $26.742 \pm 1.23 \%$, respectively. Dual isotopic values of $\delta^{15} \mathrm{~N}$ for these species showed no significant differences except for A. cristatum, which had a value of $-2.5 \pm 0.56 \%$ o (Fig. 6 )

\section{Discussion}

\subsection{Isotopic relationships and sources in water}

Liu et al. (2006) reported that on most occasions $\mathrm{N}$ isotopes in water are usually within a few per mil of zero, and this $\mathrm{O}$ isotope state roughly reflects local water versus dissolved oxygen at a 2:1 ratio (Kendall et al.,
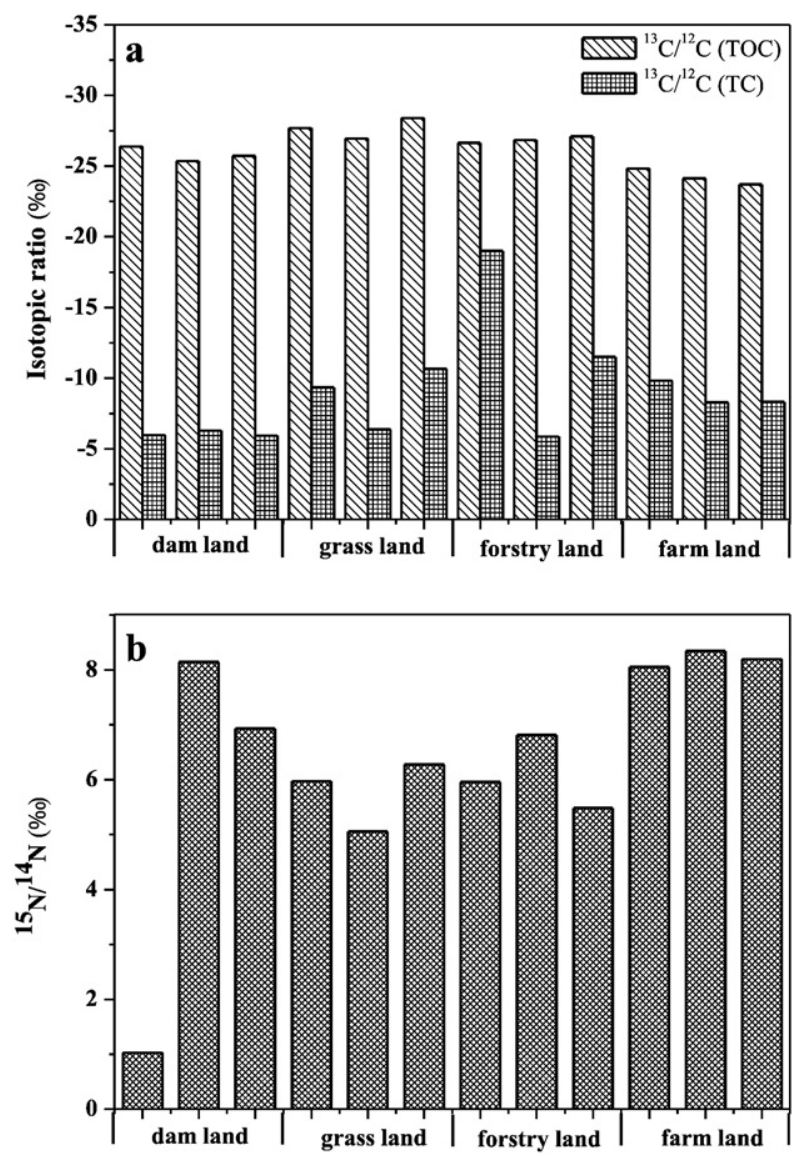

Fig. 5. Composition of stable isotope $C$ (a) and $N$ (b) under different land uses in the Yangjuangou Catchment. 


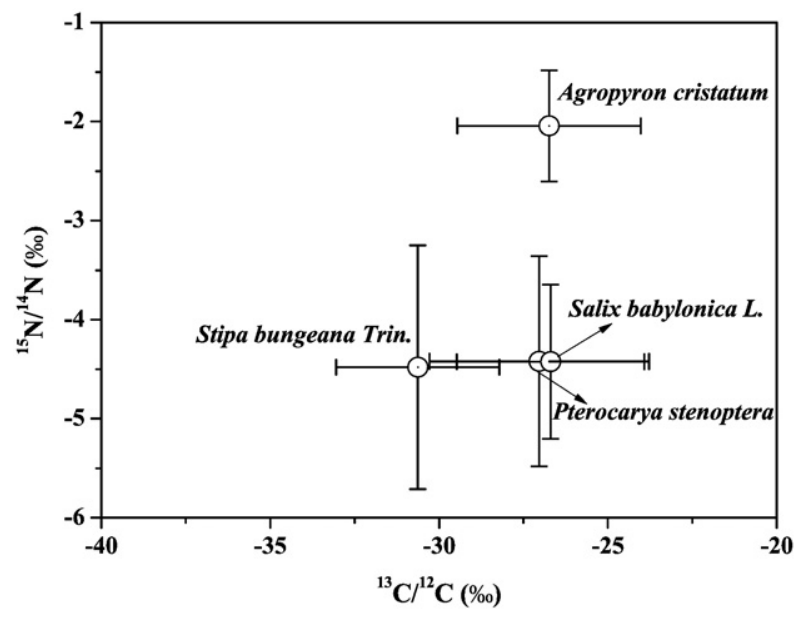

Fig. 6. Composition of stable isotopes $\mathrm{C}$ and $\mathrm{N}$ for the four main species of vegetation in the Yangjuangou Catchment.

2007). Previous studies have reported that dual isotopic values of $\delta^{15} \mathrm{~N}$ in water bodies impacted by manure range from $-2 \%$ o to $4 \%$, for which urea accounts for $0.18 \pm 1.27 \%$ o and ammonia fertilizers $0.91 \pm 0.88 \%$ 。 (Pennino et al., 2014). Most $\delta^{15} \mathrm{~N}$ in soil has been found to range from $-10 \%$ to $15 \%$ (Earl et al., 2006; Kendall, 1998), while soil that supports vegetation and soil polluted by domestic sewage range from $4 \%$ o to $9 \%$. Livestock manure could reach up to $17 \%$ o (Hale et al., 2014). In addition, Elliott et al. (2007) reported that nitrate originating from both the atmosphere and synthetic nitrate fertilizers is mainly composed of ${ }^{14} \mathrm{~N}$ and ${ }^{18} \mathrm{O}$. In our study area, which only contained villages, industrial sewage was considered to be negligible. As Fig. 7a shows, potential $\mathrm{NO}_{3}^{-}$sources in the watershed may be derived from synthetic fertilizers, soil organic $\mathrm{N}$, atmospheric deposition, sewage, and manure. Of these, we identified soil $\mathrm{N}$, fertilizers, and manure as the three main pollution sources.

The $\mathrm{O}$ atom in nitrate originates from surrounding water $\left(\mathrm{H}_{2} \mathrm{O}\right)$ and atmospheric $\mathrm{O}_{2}$. Kendall et al. (2007) suggested that the contribution of $\mathrm{O}$ atoms from local water and atmospheric $\mathrm{O}_{2}$ equates to a ratio of $2: 1$ during nitrification processes. As Fig. 3a shows, $\delta^{18} \mathrm{O}-\mathrm{NO}_{3}^{-}$values in the watershed all exceeded $8 \%$, indicating that either atmospheric nitrate was the dominant source or that nitrate from the atmosphere was intensively recycled through the organic $\mathrm{N}$ pool, thereby changing its original signature (Mayer et al., 2002; Mengis et al., 2001). The higher levels of both $\delta^{15} \mathrm{~N}-\mathrm{NO}_{3}^{-}$and $\delta^{18} \mathrm{O}-\mathrm{NO}_{3}^{-}$in the water of our study area lead us to conclude that rainfall and fertilizers from manmade or livestock sources are the major sources of nitrate in the Yangjuangou Catchment.

Telmer and Veizer (1999) and Peng et al. (2014) have shown that river DIC mainly derives from soil $\mathrm{CO}_{2}$, respiration of riverine organic matter, and the dissolution of atmospheric precipitation. Therefore, $\delta^{13} \mathrm{C}$ is commonly used to identify $\mathrm{C}$ sources due to the distinctively different ratios observed in major $\mathrm{C}$ reservoirs: $-8 \%$ o for atmospheric $\mathrm{CO}_{2}$, $0 \%$ for marine carbonates, and $-27 \%$ o to $-12 \%$ o for organic matter, which is based on $\mathrm{C}_{3}$ and $\mathrm{C}_{4}$ assimilation pathways during photosynthesis. On the other hand, other studies have shown $C_{3}$ mainly ranging from $-0.24 \%$ to $-4 \%$, $C_{4}$ mainly ranging from $-0.19 \%$ o to $-1.9 \%$, and crassulacean acid metabolism mainly ranging from $-1 \%$ o to $-2.3 \%$ 。 (Cerling et al., 2011; Garcin et al., 2014; Jin et al., 2010; Singh et al., 2005). In our study, the mean dual isotopic value of $\delta^{13} \mathrm{C}$ in the watershed was $-5.36 \pm 0.28 \%$ o (Fig. $7 \mathrm{~b}$ ), indicating that $\delta^{13} \mathrm{C}$-DIC in the Yangjuangou Catchment is mainly controlled by carbonate weathering or soil erosion but is also controlled by photosynthesis and respiration. Photosynthesis was the dominant controlling factor in surface water of the watershed. During the photosynthetic process, $\mathrm{CO}_{2}$ is absorbed
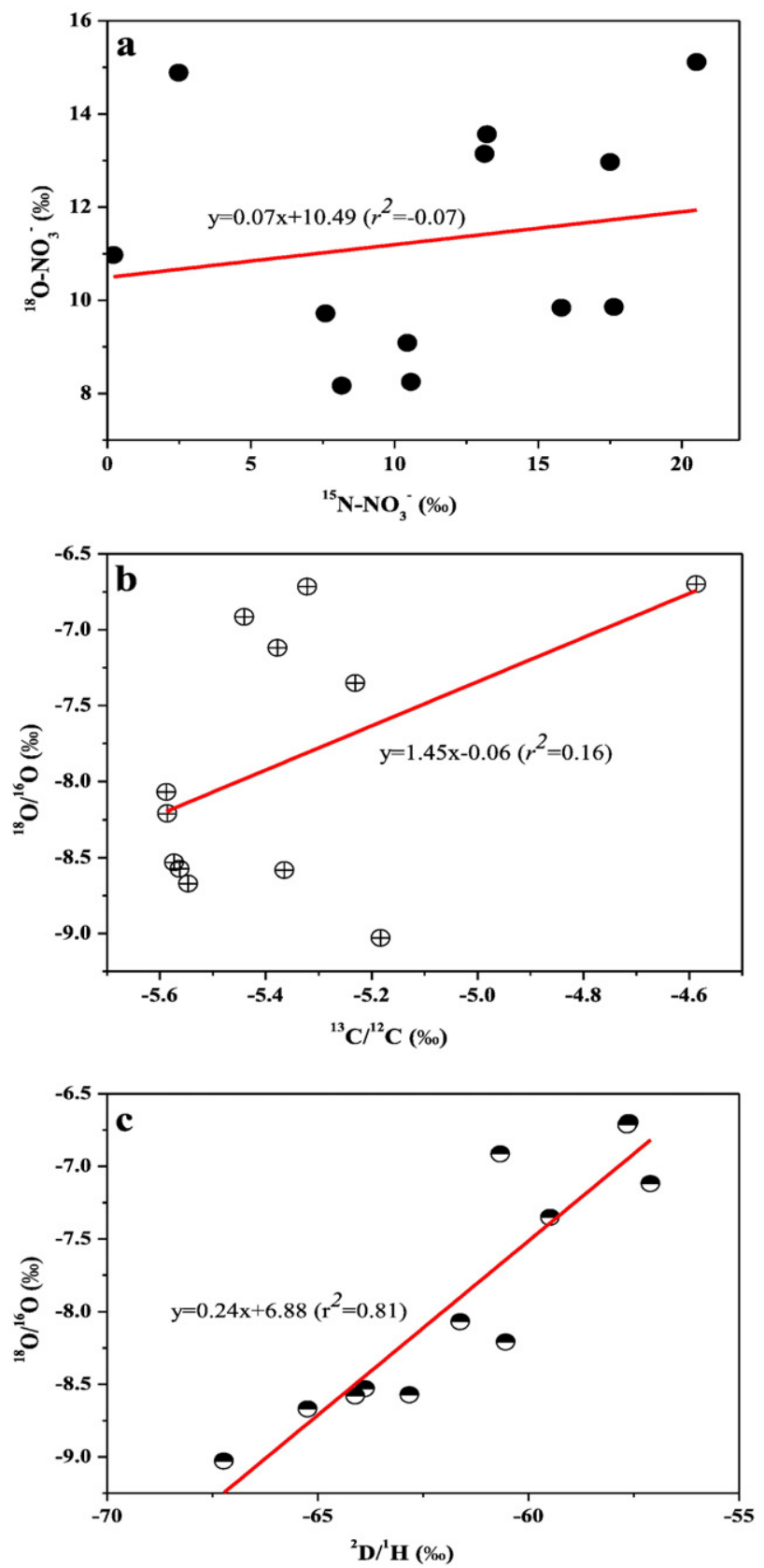

Fig. 7. Correlation of ${ }^{15} \mathrm{~N}$ and ${ }^{18} \mathrm{O}$ in nitrate (a), ${ }^{13} \mathrm{C}$ and ${ }^{18} \mathrm{O}$ in water (b), and ${ }^{2} \mathrm{D}$ and ${ }^{18} \mathrm{O}$ in water (c) in the Yangjuangou Catchment.

and ${ }^{12} \mathrm{C}$ is preferentially taken up, after which residual DIC is enriched with ${ }^{13} \mathrm{C}$ and $\delta^{13} \mathrm{C}$-DIC becomes more positive (Gao et al., 2014, 2016).

The stable isotopic composition of $\delta^{18} \mathrm{O}$ and $\delta^{2} \mathrm{D}$ in water bodies provides insight into the sources and mixing effects of water masses as well as the interaction of water with rocks and minerals (Baskaran et al., 2016; Raidla et al., 2011). Average annual $\delta^{18} \mathrm{O}$ and $\delta^{2} \mathrm{D}$ values can be used to track the pathway of water moisture as well as the dominant sources of water (Hren et al., 2009; Tian et al., 2007). However, Gat (1996) believed that atmospheric moisture during tropical storms that have very low $\delta^{2} \mathrm{D}$ and $\delta^{18} \mathrm{O}$ values cannot be fully explained by the usual assumptions related to precipitation and temperature. In our study, $\delta^{18} \mathrm{O}$ was $-7.87 \pm 0.85 \%$ 。 in the watershed (Fig. $7 \mathrm{c}$ ), which is similar to $\delta^{18} \mathrm{O}$ values of $6.5 \%$ o during tropical storms and low-pressure systems reported in Puerto Rico (Scholl et al., 2009). This could be explained by the "amount effect," with lower values associated with higher rainfall amounts and by cloud altitude and atmospheric 
condensation temperature (Scholl et al., 2009). In addition, Adame et al. (2016) reported that the characteristic isotopic composition of water from rainfall generates an almost immediate response in the isotopic composition of river flow.

We found a high positive correlation between $\delta^{2} \mathrm{D}$ and $\delta^{18} \mathrm{O}\left(r^{2}=\right.$ 0.81 ; Fig. 7c), indicating that $\delta^{2} \mathrm{D}$ was a function of $\delta^{18} \mathrm{O}$. In our study, the mean dual isotopic value of $\delta^{2} \mathrm{D}$ was $-61.49 \pm 3.25 \%$, which is similar to the $\delta^{2} \mathrm{D}$ values of rivers and rainfall (40\%-50\%) in the eastern USA during hurricanes (Higgins, 2012). The similarity in our findings of $\delta^{2} \mathrm{D}$ and $\delta^{18} \mathrm{O}$ values to those reported for storm-type systems suggests that the catchment is subjected to variations in water sources and/or precipitation mechanisms (Bowen, 2012), which would lead to soil erosion and runoff effects that subsequently produce a wide range of isotopic values.

\subsection{Characteristics of $C$ and $N$ isotopes in the watershed}

Ojima et al. (1993) reported that $\delta^{13} \mathrm{C}$ values in soil along with $C_{3}$ inputs ranged from $24 \%$ o to $29 \%$ and that soil along with $C_{4}$ inputs ranged from $12 \%$ to $13 \%$. In our study, we found that $\delta^{13} \mathrm{C}$ values for rainfall, water, and TC in soil mainly ranged from $-10 \%$ o to $-5 \%$, but $\delta^{13} \mathrm{C}$ TOC values for soil were much less (from $-30 \%$ o to $-20 \%$ ) (Fig. 8). We attribute this discrepancy to the higher levels of $\delta^{13} \mathrm{C}$-DIC for water, rainfall, and soil. This also provides evidence that DIC in the catchment water mainly derives from precipitation and associated runoff. However, $\delta^{13} \mathrm{C} / \delta^{12} \mathrm{C}$ values for the plants were close to the $\delta^{13} \mathrm{C}$-TOC values for soil, indicating that the litter from the sampled species is a major source of $C$ in the watershed soil. This is because in the Yangjuangou Catchment, severe erosion typically occurs on grassy $\left(C_{4}\right)$ land-use types devoid of woody vegetation $\left(C_{3}\right)$, whereas channel banks can typically maintain some degree of woody vegetative cover. Accordingly, we consider that $\delta^{13} \mathrm{C}$ could be used to discriminate between sediment derived from these distinct subsoil sources.

We found that the $\delta^{15} \mathrm{~N}$ values in water corresponded to soil and rainfall but did not correspond to plants, indicating that plants were not the major source for $\mathrm{N}$ in water (Fig. 8). Animal manure and manure-derived fertilizers have high $\delta^{15} \mathrm{~N}$ (Finlay and Kendall, 2007) and landscapes or channel banks may impact soil $\delta^{15} \mathrm{~N}$ due to their different anaerobic conditions; they may also increase denitrification, which favors the accumulation of ${ }^{15} \mathrm{~N}$ (Mukundan et al., 2010). Therefore, the $\delta^{15} \mathrm{~N}$ values we obtained showed differences between cultivated sources with waste-derived fertilizer inputs and subsoil in runoff (Yang et al., 2015, 2016).

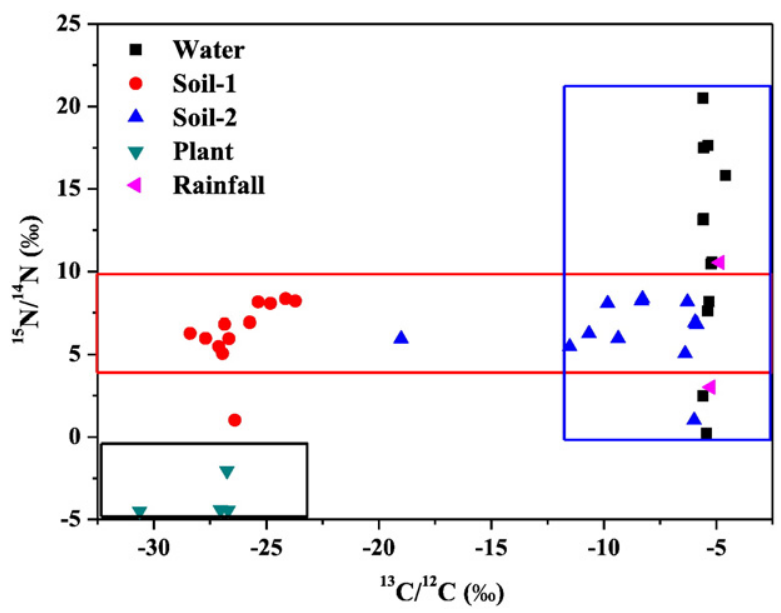

Fig. 8. Scatter diagram of $\delta^{13} \mathrm{C} / \delta^{12} \mathrm{C}$ versus $\delta^{15} \mathrm{~N} / \delta^{14} \mathrm{~N}$ in the water, soil, and plant samples in the Yangjuangou Catchment. Note: soil-1 and soil-2 indicate $\delta^{13} \mathrm{C}$-TOC and $\delta^{13} \mathrm{C}$-TC respectively.

\section{Conclusions}

This study demonstrated that land-use types, climate change, and vegetation could be important factors that regulate variations in stable isotopes of $\mathrm{C}, \mathrm{N}, \mathrm{H}$, and $\mathrm{O}$ in stream water and soil in typical watersheds in the Loess Plateau. The spatial distribution of concentrations and isotopes of $\mathrm{C}, \mathrm{N}, \mathrm{H}$, and $\mathrm{O}$ in water bodies, soil, and vegetation reflect the heterogeneity and complexity of the Yangjuangou Catchment. Isotopic values indicated that $\mathrm{C}$ and $\mathrm{N}$ in most water samples are mainly derived from manure sources, soil erosion, and a mixture of chemical fertilizers and manure during rainfall events. Moreover, volatilization and denitrification processes may affect $\mathrm{C}, \mathrm{N}, \mathrm{O}$, and $\mathrm{H}$ isotopic composition in this catchment. Lastly, the high temperatures and rainfall of the Yangjuangou Catchment during the rainy season may also increase the extent of $\mathrm{C}$ and $\mathrm{N}$ loss.

\section{Acknowledgements}

The authors thank all anonymous reviewers for their helpful remarks. This work was financially supported by the National Nature Science Foundation of China (41571130083 and 41390464), the State Key Laboratory of Urban and Regional Ecology Open Fund, the Research Center (SKLURE2015-2-2) for Eco-Environmental Sciences, the Chinese Academy of Sciences (CAS), and the Youth Innovation Promotion Association, CAS.

\section{References}

Adame, M.F., Fry, B., Bunn, S.E., 2016. Water isotope characteristics of a flood: Brisbane River, Australia. Hydrol. Process. 30, 2033-2041.

Baskaran, M., Novell, T., Nash, K., Ruberg, S.A., Johengen, T., Hawley, N., Klump, J.V., Biddanda, B.A., 2016. Tracing the seepage of subsurface sinkhole vent waters into Lake Huron using radium and stable isotopes of oxygen and hydrogen. Aquat. Geochem. 22, 349-374.

Bowen GJ. 2012. http://wateriso.utah.edu/waterisotopes/pages/data_access/ghd.html. (Accessed February 2014).

Brunet, F., Gaiero, D., Probst, J.L., Depetris, P.J., Lafaye, G.F., Stille, P., 2005. $\delta^{13} \mathrm{C}$ tracing of dissolved inorganic carbon sources in Patagonian rivers (Argentina). Hydrol. Process. 19, 3321-3344

Cerling, T.E., Wynn, J.G., Andanje, S.A., Bird, M.I., Korir, D.K., Levin, N.E., Mace, W., Macharia, A.N., Quade, J., Remien, C.H., 2011. Woody cover and hominin environments in the past 6 million years. Nature 476, 51-56.

Cheng, L., Liu, W., 2014. Study of water movement and ground water recharge for the Loess Tableland using environment tracers. Am. Soc. Agric. Biol. Eng. 57 (1), 23-30.

Earl, S.R., Valett, H.M., Webster, J.R., 2006. Nitrogen saturation in stream ecosystems. Ecology 87 (12), 3140-3151.

Elliott, E.M., Kendall, C., Wankel, S.D., Burns, D.A., Boyer, E.W., Harlin, K., Bain, D.J., Butler, T.J., 2007. Nitrogen isotopes as indicators of $\mathrm{NO}_{\mathrm{x}}$ source contributions to atmospheric nitrate deposition across the Midwestern and northeastern United States. Environ. Sci. Technol. 41, 7661-7667.

Finlay, J.C., Kendall, C., 2007. Stable isotope tracing of temporal and spatial variability in organic matter sources to freshwater ecosystems, Chapter 10. In: Michener, R.H., Lajtha, K. (Eds.), Stable Isotopes in Ecology and Environmental Science, second ed. Blackwell Publishing, pp. 283-333.

Garcin, Y., Schefuss, E., Schwab, V.F., Garreta, V., Gleixner, G., Vincens, A., Todou, G., Séné, O., Onana, J.M., Achoundong, G., Sachse, D., 2014. Reconstructing $C_{3}$ and $C_{4}$ vegetation cover using n-alkane carbon isotope ratios in recent lake sediments from Cameroon, Western Central Africa. Geochim. Cosmochim. Acta 142, 482-500.

Gat, J.R., 1996. Oxygen and hydrogen isotopes in the hydrologic cycle. Annu. Rev. Earth Planet. Sci. 24, 225-262.

Gao, Y., Yu, G.R., Yang, T.T., Jia, Y.L., He, N.P., Zhuang, J., 2016. New insight into global blue carbon estimation under human activity in land-sea interaction area: a case study of China. Earth Sci. Rev. 159, 36-46.

Gao, Y., Zhu, X.J., Yu, G.R., He, N.P., Wang, Q.F., Tian, J., 2014. Water use efficiency threshold for terrestrial ecosystem carbon sequestration under afforestation in China. Agric. For. Meteorol. 195-196, 32-37.

Hale, R.L., Turnbull, L., Earl, S., Grimm, N., Riha, K., Michalski, G., Lohse, K.A., Childers, D., 2014. Sources and transport of nitrogen in arid urban watersheds. Environ. Sci. Technol. 48 (11), 6211-6219.

Heaton, P., Reichenbacher, L. Sauter, D. Allen, R., Scott, S., Hill, E., 2012. Measuring the effects of alexithymia on perception of emotional vocalizations in autistic spectrum disorder and typical development. Psychol. Med. 42, 2453-2459.

Higgins, P., 2012. http://paleopix.com/blog/2012/11/07/more-about-sandy/ (Accesed September 2014).

Hren, M.T., Bookhagen, B., Blisniuk, P.M., Booth, A.L., Chamberlain, C.P., 2009. $\delta^{18} O$ and $\delta^{2} D$ of streamwaters across the Himalaya and Tibetan Plateau: implications for moisture sources and paleoelevation reconstructions. Earth Planet. Sci. Lett. 288, 20-32. 
Lehmitz, R., Maraun, M., 2016. Small-scale spatial heterogeneity of stable isotopes signatures $\left(\delta^{15} \mathrm{~N}, \delta^{13} \mathrm{C}\right)$ in Sphagnum sp. transfers to all trophic levels in oribatid mites. Soil Biol. Biochem. 100, 242-251.

Liu, C.Q., Li, S.L., Lang, Y.C., Xiao, H.Y., 2006. Using $\delta^{15} \mathrm{~N}$ - and $\delta^{18} \mathrm{O}$-values to identify nitrate sources in karst ground water, Guiyang, Southwest China. Environ. Sci. Technol. 40, 6928-6933.

Liu, Y.H., 2011. Biomass and its allocation of the main vegetation types in Liupan mountains. For. Res. 24 (4), 443-452.

Liu, Y., Liu, F., Dorland, E., 2015. Variations of soil water isotopes and effective contribution times of precipitation and through fall to alpine soil water, in Wolong Nature Reserve, China. Catena 126, 201-208.

Jin, L., Ravella, R., Ketchum, B., Bierman, P.R., Heaney, P., White, T., Brantley, S.L., 2010. Mineral weathering and elemental transport during hillslope evolution at the Susquehanna/Shale Hills Critical Zone Observatory. Geochim. Cosmochim. Acta 74, 3669-3691.

Kendall, C., 1998. Tracing nitrogen sources and cycling in catchments. In: Kendall, C., McDonnell, J.J. (Eds.), Isotope Tracers in Catchment Hydrology. Amsterdam, Elsevier Science BV, pp. 519-576.

Kendall, C., Elliott, E.M., Wankel, S.D., 2007. Tracing anthropogenic inputs of nitrogen to ecosystems. In: Lajtha, K., Michener, R. (Eds.), Stable Isotopes in Ecology and Environmental Science, second ed. Blackwell, UK, pp. 375-449.

Masetti, M., Poli, S., Simone, S., 2008. Spatial and statistical assessment of factors influencing nitrate contamination in groundwater. J. Environ. Manag. 86 (1), 272-281.

McMahon, P.B., Böhlke, J.K., 2006. Regional patterns in the isotopic composition of natural and anthropogenic nitrate in groundwater, High Plains, U.S.A. Environ. Sci. Technol. 40 (9), 2965-2970.

Mukundan, R., Radcliffe, D.E., Risse, L.M., 2010. Spatial resolution of soil data and channel erosion effects on SWAT model predictions of flow and sediment. J. Soil Water Conserv. 65 (2), 92-104.

Mayer, B., Boyer, E.W., Goodale, C., Jaworski, N.A., Van Breemen, N., Howarth, R.W., Seitzinger, S., Billen, G., Lajtha, K., Nadelhoffer, K., 2002. Sources of nitrate in rivers draining sixteen watersheds in the northeastern US: isotopic constraints. Biogeochemistry 57, 171-197.

Mengis, M., Walther, U., Bernasconi, S.M., Wehrli, B., 2001. Limitations of using $\delta^{18} \mathrm{O}$ for the source identification of nitrate in agricultural soils. Environ. Sci. Technol. 35, $1840-1844$.

Miller, G.H., Alley, R.B., Brigham-Grette, J., Fitzpatrick, J.J., Polyak, L., Serreze, M., White, J.W.C., 2010. Arctic amplification: can the past constrain the future? Quat. Sci. Rev. 29, 1779-1790.

Ojima, D.S., Valentine, D.W., Mosier, A.R., Parton, W.J., Schimel, D.S., 1993. Effect of land use change on methane oxidation in temperate forest and grassland soils. Chemosphere 26, 675-685.

Panno, S.V., Hackley, K.C., Hwang, H.H., Greenberg, S.E., Krapac, I.G., Landsberger, S. O'Kelly, D.J., 2006. Characterization and identification of $\mathrm{Na}-\mathrm{Cl}$ sources in ground water. Ground Water 44, 176-187

Pennino, M.J., Kaushal, S.S., Beaulieu, J.J., Mayer, P.M., Arango, C.P., 2014. Effects of urban stream burial on nitrogen uptake and ecosystem metabolism: implications for watershed nitrogen and carbon fluxes. Biogeochemistry 121 (1), 247-269.

Peng, X., Liu, C.Q., Wang, B.L., Zhao, Y.C., 2014. The impact of damming on geochemical behavior of dissolved inorganic carbon in a karst river. Chin. Sci. Bull. 59 (19), 2348-2355.
Proemse, B.C., Mayer, B., Fenn, M.E., 2012. Tracing industrial sulfur contributions to atmospheric sulfate deposition in the Athabasca Oil Sands Region, Alberta, Canada. Appl Geochem. 27, 2425-2434.

Raidla, V., Kirsimae, K., Vaikmae, R., Jõeleht, A., Karro, E., Marandi, A., Savitskaja, L., 2011. Geochemical evolution of groundwater in the Cambrian-Vendian aquifer system of the Baltic Basin. Chem. Geol. 258, 219-231.

Schachtschneider, K., February, E., 2007. Unravelling the mystery of tree water uptake along a Namibian ephemeral river-which tree gets what and from where? S. Afr. J. Bot. 73, 310-311.

Scholl, M.A., Shanley, J.B., Zegarra, J.P., Coplen, T.B., 2009. The stable isotope amount effect: new insights from NEXRAD echo tops, Luquillo Mountains, Puerto Rico. Water Resour. Res. 45, 1-14.

Schulte, P., van Geldern, R., Freitag, H., Karim, A., Négrel, P., Petelet-Giraud, E., Probst, A. Probst, J.L., Telmer, K., Veizer, J., Barth, J.A.C., 2011. Applications of stable water and carbon isotopes in watershed research: weathering, carbon cycling, and water balances. Earth Sci. Rev. 109, 20-31.

Singh, S.K., Sarin, M.M., France-Lanord, C., 2005. Chemical erosion in eastern Himalaya: major ion composition of the Brahmaputra and ${ }^{13} \mathrm{C}$ of dissolved inorganic carbon. Geochim. Cosmochim. Acta 69, 3573-3588.

Spötl, C., 2005. A robust and fast method of sampling and analysis of $\delta^{13} \mathrm{C}$ of dissolved inorganic carbon in ground waters. Isot. Environ. Health Stud. 41 (3), 217-221.

Telmer, K., Veizer, J., 1999. Carbon fluxes, $\mathrm{pCO}_{2}$ and substrate weathering in a large northern river basin, Canada: carbon isotope perspectives. Chem. Geol. 159, 61-86.

Tian, L., Yao, T., MacClune, K., White, J.W.C., Schilla, A., Vaughn, B., Vachon, R., Ichiyanagi, K., 2007. Stable isotopic variations in west China: a consideration of moisture sources. J. Geophys. Res. 112.

Wan, H., Liu, W.G., 2016. An isotope study $\left(\delta^{18} \mathrm{O}\right.$ and $\left.\delta \mathrm{D}\right)$ of water movements on the Loess Plateau of China in arid and semiarid climates. Ecol. Eng. 93, 226-233.

Wang, Y.F., Fu, B.J., Lv, Y.H., Song, C.J., Luan, Y., 2010. Local scale spatial variability of soil organic carbon and its stock in the hilly area of Loess Plateau. Quat. Res. 73, 70-76.

Wang, Y.F., Fu, B.J., Lv, Y.H., Chen, L.D., 2011. Effects of vegetation restoration on soil organic carbon sequestration at multiple scales in semi-arid Loess Plateau, China. Catena $85,58-66$.

Wang, Y.F., Chen, L.D., Gao, Y., Wang, S., Lü, Y.G., Fu, B.J., 2014. Carbon sequestration function of check-dams: a case study of the Loess Plateau in China. Ambio 43 (7) 926-931.

Wassenaar, L.I., Athanasopoulos, P., Hendry, M.J., 2011. Isotope hydrology of precipitation, surface and ground waters in the Okanagan Valley, British Columbia, Canada. J. Hydrol. 411, 37-48.

Weynell, M., Wiechert, U., Zhang, C.J., 2016. Chemical and isotopic (O, H, C) composition of surface waters in the catchment of Lake Donggi Cona (NW China) and implications for paleoenvironmental reconstructions. Chem. Geol. 435, 92-107.

Yang, T, Gao, X, Sorooshian, S., Li, X, 2016. Simulating California reservoir operation using the classification and regression-tree algorithm combined with a shuffled cross-validation scheme. Water Resour. Res. 52 (3), 1626-1651.

Yang, T., Gao, X., Sellars, S.L., Sorooshian, S., 2015. Improving the multi-objective evolutionary optimization algorithm for hydropower reservoir operations in the California Oroville-Thermalito complex. Environ. Model Softw. 69, 262-279.

Yue, F.J., Li, S.L., Liu, C.Q., Lang, Y.C., Ding, H., 2015. Sources and transport of nitrate constrained by the isotopic technique in a karst catchment: an example from Southwest China. Hydrol. Process. 29, 1883-1893. 